How to Cite

Mantra, I. B. N., Suwandi, I. N., Sukanadi, N. L., Astuti, N. K. W., \& Indrawati, I. G. A. P. T. (2019). Teachers' competences in dealing with instructional constraints to develop higher quality of learning. International Journal of Social Sciences, 2(1), 44-48. https://doi.org/10.31295/ijss.v3n1.95

\title{
Teachers' Competences in Dealing with Instructional Constraints to Develop Higher Quality of Learning
}

\author{
Ida Bagus Nyoman Mantra \\ Universitas Mahasaraswati Denpasar, Indonesia \\ Corresponding author email: bagusmantra@unmas.ac.id
}

\author{
I Nyoman Suwandi \\ Universitas Mahasaraswati Denpasar, Indonesia \\ Email: nyomansuwandi11@gmail.com
}

\author{
Ni Luh Sukanadi \\ Universitas Mahasaraswati Denpasar, Indonesia \\ Email:luhsukanadi@yahoo.co.id \\ Ni Ketut Wendi Astuti \\ Universitas Mahasaraswati Denpasar, Indonesia \\ Email: baguspapers@gmail.com \\ I Gusti Ayu Putu Tuti Indrawati \\ Universitas Mahasaraswati Denpasar, Bali, Indonesia \\ Email: igap_tutiindrawati@yahoo.com
}

\begin{abstract}
Competence is usually associated with highly professional performance and there is a direct link in the field of education between a teacher's professional competence and students' performance. The present study explores teachers' competences in dealing with instructional constraints to develop a higher quality of learning. The participants were pre-service junior high school teachers. The analysis includes teachers' strategies in encountering the various constraints and problem faced by the teachers in conducting teaching and learning process. This study made use of a qualitative research design in which the data were analyzed analytically with deep argumentation and presented descriptively. Data were collected through direct observation and in-depth interviews with the selected junior high school teachers. The findings of the present study indicated that pre-service junior school teachers employed some strategies in dealing with the students' learning constraints which mainly modifying teaching strategies and motivating the students to learn more actively. This study suggests that teachers should continually develop their competence in dealing with various problems found in the classroom.
\end{abstract}

Keywords---constraints, instructional, learning quality, teacher competences.

\section{Introduction}

Education is essentially important for the development of every nation in the world to become sustainable in the globalization era (Bertschy et al., 2013). Efforts to improve the quality of education is a must to be carried out continuously so that a nation can progress and develop along with the advancement of science and technology (Maba et al., 2018). Some efforts have been carried out including improving the curriculum, increasing teacher competencies through upgrading, improving educational facilities, and others. This was done to improve the quality of national education. The success of education is determined by the success of the implementation of teaching and

ISSN 2632-9409

Received Jan 27, 2019 / Accepted Jun 18, 2019 / Published Jul 31, 2019 
learning activities, namely the integration between the activities of teachers with student activities (Maba et al., 2018). One effort to optimize learning is to improve teaching that is much influenced by the teacher because teaching is a system, then the improvements must also include all components in the teaching system. The most important components are goals, material, and assessment. The assessment should be conducted to improve learning (Widiastuti, 2016; Margunayasa, 2018).

A teacher is key to the success of an educational institution. Teachers' competences in teaching are definitely influence the quality of the educational process offered by the educational institutions (Maba et al., 2017; Mantra, 2017). Therefore these teacher resources must be developed both through education and training and other activities so that their professional abilities continually improve. It can be said that the main factors that determine the quality of education are the teacher's competence. A teacher is at the forefront of creating quality human resources. A teacher faces directly with the students in the class through the teaching and learning process. Therefore, a teacher who has high qualifications, competence, and dedication is needed in carrying out the assigned professional duties (Sugiharti, 2016).

A teacher is a professional profession, it means that having a position that requires special skills (Numrich, 1996). The duties of a teacher as a profession includes educating, teaching and training. Educating means continually developing life values for the students. Teaching means continuing and developing science and technology, while training means developing skills of the students. Teachers must have academic qualifications, competencies, educator certificates, physical and spiritual health, and can realize national education goals. Teacher competencies include pedagogical competencies, personality competencies, social competencies and professional competencies obtained through professional education (Nabila, 2016; Maba \& Mantra, 2018; Seferoglu, 2006).

Professionalism in teaching is required by a teacher. A teacher must be sensitive and responsive to changes, renewal and science, and technology that is continually developed in line with the needs of society and the times (Mudiono, 2016). This is where the teacher's job is to always improve knowledge of science, improve the quality of education so that what is given to students is not too behind the progress of the times (Sugiharti, 2016). The reality now is that many teachers are not professional in carrying out their duties. Many teachers teach subject matter that is not relevant to the mastered field, with reasons for filling in empty hours, stakeholders' requirements, and many other reasons. Most teaching methods used by teachers when teaching are only monotonous, it is not adapted to the subject matter and psychological conditions of students. In addition to the above problems, many teachers are unprofessional in carrying out their duties due to the lack of facilities and infrastructure in the school where they teach and various kinds of life problems, whether personal, family or community, as well as such things that cause teachers unprofessional in conducting learning process.

The duties and roles of teachers from day to day are getting heavier along with the development of science and technology. Teachers as the main component in education are required to be able to balance even beyond the development of science and technology (Sikki et al., 2013). Through the hard efforts of teachers at the school, it is expected to be able to produce students who have high competence and are ready to face the challenges of life with strong confidence (Wayne \& Youngs, 2003). Therefore, it is necessary to change the developed mindset, from the traditional mindset to the professional mindset. Teachers should have a vision for the future and can see the challenges to face uncertain world changes that require good skills and readiness (Bhargava \& Pathy, 2011).

Therefore, to raise the degree and dignity of teachers, teachers must have standard competency qualifications, namely pedagogical competence, personality competence, personal competence, and professional competence (Maba et al., 2017; Hakim, 2015). Through these competencies that must be mastered by teachers, then professional teachers can be easily realized who can truly provide knowledge to students and can be an example or role model for students or society (Kizilaslan, 2011). The relevance of competencies in implementing the teaching and learning process is the implementation phase of the program that has been prepared (Koksal, 2013). In this activity the ability demanded is the activity of the teachers to create and grow the activities of students learning following the plans that have been prepared. Teachers must be able to make decisions based on the right assessment, whether teaching and learning activities are sufficient, whether the method is changed, whether the past activities need to be repeated when students have not been able to achieve learning goals.

In the implementation of the teaching and learning process, teachers should be competent in the management of learning and delivering the subject matter according to the learning plan in a systematic manner, so that the teaching objectives can be mastered by students effectively and efficiently. Evaluation is the process of determining whether the material and learning methods are according to the expected goals. The evaluation can be done by giving an appropriate assessment. The tests used to assess can be in the form of a written test, an oral test, and a productive test (Widiastuti \& Saukah, 2017; Maba et al., 2018). Assessment is not only intended to see students' ability but it is also to improve learning because teachers can see their problems and weaknesses of their teaching through the result of the students' assessment 


\section{Research Method}

A qualitative approach was used to analyze the data of the study. In this study, the data about the pre-service teachers' competences in dealing with the teaching constraints were discussed argumentatively and presented descriptively. The data were collected by doing classroom observations and in-depth interviews with the pre-service junior high school teachers. The participants of the study were chosen by doing random sampling technique to get various data regarding the teachers' assessment practices. The interviews were conducted in relax situation to the teachers to get valid and reliable data. An interview guide was the instrument used to collect data related to teachers' assessment models. The data were also collected by doing direct observation. In this study, researchers conducted observations on teaching activities directly in the classroom. Observations were conducted to triangulate the data found from the interviews, therefore reliable findings can be established for the present study. The data obtained from interviews were firstly transcribed and then interpreted. The transcription of the interview and observation were coded into categories. Then the categorized data were analyzed and described and presented argumentatively.

\section{Discussion}

Learning is a transactional communication process that is reciprocal effectively and efficiently between teachers and students as well as between students and other students to achieve the stated goals. The essence of transactional communication is the delivery of various kinds of ideas, thoughts, messages, etc. Consequently, many constraints and obstacles faced by teachers in the learning process.

A teacher in the teaching and learning process has an important role as an agent of learning and change. As agents of learning change, teachers must have sufficient academic qualifications and interactional skills. There are still many inexperienced teachers assigned to teachers who cannot really operationalize and developed the learning plan in the actual teaching and learning process teachers, in this case, need to be really competence to deliver the learning process, in addition to academic qualifications, a teacher is required to have pedagogical competencies that enable the teacher to manage and develop an interesting, fun and challenging based teaching and learning process.

There are many obstacles and constraints found by the teachers in carrying out their duties. The first constraint comes from the facilities and infrastructure supporting the teaching and learning process. For example, less comfortable and representative study rooms, inadequate quantity and quality of learning media. Likewise, the books needed by teachers and students are not available. Therefore learning facilities should always be available for the students in order the can develop their higher way of learning.

The second constraint comes from the quality of the students. In general, students still have very low motivation, reluctant willingness and poor interest in learning. The logical consequence is that teachers need to be continually aware of their student's condition. The condition of the quality of such students is certainly a very significant obstacle in managing and developing the teaching and learning to be conducive for students' active and creative participation. The results of the research have shown and proven that the quality of students also determines the success of a teacher in managing, building and developing the learning process. For example, motivation to learn has been recognized as a key factor that is the golden bridge to success in the learning process in any subject.

Based on the classroom observation, it is found that is very difficult for teachers to develop multiple-direction communication. The process of teaching and learning at this time still tends to be dominated by the teachers and the teaching method is mainly lecturing. The students only become passive listeners, so the process and atmosphere of teaching and learning become monotone, less interesting, challenging and boring. This process of teaching and learning is certainly an indicator of the inability of teachers to implement the learning plans they have prepared previously. There are only a few teachers adapted the teaching activities using more innovative learning models.

There are still many obstacles and constraints in designing and developing lesson plans and implementing competency-based learning. In designing and making a plan for implementing learning for competency-based learning, the teachers are challenged because: (1) there is no complete competency-based curriculum and syllabus that can be used as a guidance; (2) lack of experience in making lesson plans and unavailability of lesson plan examples; (3) absence of direction and guidance on procedures for designing and making lesson for competencybased English learning; and the reluctance of the teachers to make the learning plan.

Obstacles and constraints faced by teachers in implementing and developing competency-based learning, as described above, include (1) students' low motivation, willingness, and interest in learning, (2) low and limited levels of learning mastery, and (3) the limited facilities and infrastructure supporting competency-based teaching and 
learning. In general, the obstacles and constraints of competency-based teaching and learning are indeed quite significant. However, as agents of learning change, teachers must brave to be responsible for the low level of students' mastery without the need to look for the scapegoat, because after the scapegoat is found the problem will not be solved automatically. That is, a teacher must continue to strive to improve the quality of learning so that learning competencies can be achieved better.

Based on observation notes and interviews results in overcoming obstacles and constraints that arise in the teaching and learning process the teachers carry out remedial actions that have temporary dimensions and the results are far from satisfying. The actions taken include: (1) they consistently and continuously strive to motivate and encourage students to be diligent. Therefore, in each learning process students are always reminded that motivation is a key factor in learning success to gain skills and (2) they explained and provided examples of effective ways of learning.

From the explanation above, it is clear that the obstacles and constraints faced by teachers in managing competency-based learning are very basic and crucial. The fundamental and crucial obstacle lies in the quality of students. In this era of globalization which was marked by the rapid development of science and technology as well as increasingly intense competition in the labor market, the quantitative approach in the recruitment system for new students should be shifted and directed towards a qualitative approach. It must be realized and anticipated that in the future only qualified human resources will have the opportunity to win increasingly competitive labor market competition. The indication in this direction is visible.

To overcome and minimize any obstacles and constraints that arise in the process of learning, the teacher must act concretely in line with the principles of competency-based learning, namely managing and developing learning that: (1) focuses on students, (2) able to develop the creativity of students, (3) interesting, fun and challenging, (4) contextual or meaningful for students, (5) varied and varied, and (6) provide more opportunities for learning.

To be able to manifest the management and learning which reflects the conditions above, the task of the teacher of learning and change is certainly very hard. That is, the competency-based learning principles above can only be manifested in the real learning process, if they have sufficient relevant academic qualifications and qualified and varied classroom management skills, such as styles and patterns of communication and interaction. In other words, subject matter teachers must have personality competencies, professional competencies, pedagogical competencies, and social competencies.

\section{Conclusion}

Teachers need to possess a high level of competence in dealing with various problems found in the classroom. This is important because classroom learning constraints and learning problem are getting more complex along with the development of technology and the advancement of communication system nowadays. Moreover, students' needs are getting more complex too, therefore the learning activity should be conducted to be able to fulfill the students' needs. Without conducting proper and adequate learning activities to meet the students' needs, students may have insufficient competent in facing the globalization era. Consequently, to meet the learning expectation, teachers should be equipped with high professional competences to provide a higher quality of learning.

\section{Acknowledgments}

The authors would like to thank the editor of IJSS for their valuable time, support and advice in completing the current study.

\section{References}

Bertschy, F., Künzli, C., \& Lehmann, M. (2013). Teachers' competencies for the implementation of educational offers in the field of education for sustainable development. Sustainability, 5(12), 5067-5080. https://doi.org/10.3390/su5125067

Bhargava, A., \& Pathy, M. (2011). Perception of student teachers about teaching competencies. American International Journal of Contemporary Research, 1(1), 77-81.

Hakim, A. (2015). Contribution of competence teacher (pedagogical, personality, professional competence and social) on the performance of learning. The International Journal Of Engineering And Science (IJES), 4(2), 1-12.

Kizilaslan, I. (2011). ELT student teachers'competence for teaching language skills: a qualitative exploration. International Journal of Social Sciences and Humanity Studies, 3(1), 161-169. 
Köksal, N. (2013). Competencies in teacher education: Preservice teachers' perceptions about competencies and their attitudes. Educational research and reviews, 8(6), 270.

Maba, W., \& Mantra, I. B. N. (2018). The primary school teachers' competence in implementing the 2013 curriculum. In SHS Web of Conferences (Vol. 42, p. 00035). EDP Sciences. https://doi.org/10.1051/shsconf/20184200035

Maba, W., Perdata, I. B. K., \& Astawa, I. N. (2017). Constructing assessment instrument models for teacher's performance, welfare and education quality. International journal of social sciences and humanities, 1(3), 88-96. https://doi.org/10.29332/ijssh.v1n3.59

Maba, W., Perdata, I. B. K., \& Putra, I. G. N. N. (2018). Classroom action research practices of state high school teachers in Bali province. International research journal of management, IT and social sciences, 5(5), 54-60. https://doi.org/10.21744/irjmis.v5n5.288

Maba, W., Perdata, I. B. K., Astawa, I. N., \& Mantra, I. B. N. (2018). Conducting assessment instrument models for teacher competence, teacher welfare as an effort to enhance education quality. International Research Journal of Management, IT and Social Sciences, 5(3), 46-52.

Mantra, I. B. N. (2017). Promoting primary school teachers' competence through dynamic interactive workshop and partnership. International Journal of Linguistics, Literature and Culture, 3(1), 1-6.

Margunayasa, I. G. (2018). Improving teachers competency through strengthening of teachers group work based on lesson study. International Journal of Social Sciences and Humanities, 2(2), 87-98. https://doi.org/10.29332/ijssh.v2n2.132

Mudiono, A. (2016). Keprofesionalan Guru dalam Menghadapi Pendidikan di Era Global. In Prosiding Seminar Nasional Jurusan KSDP-Prodi S1 PGSD UNM (pp. 43-50).

Nabila, H. (2016, September). The Influence of Pedagogic Competence and Professional Competence to Performance of Teachers Social Studies in Trowulan District. In International Conference on Ethics of Business, Economics, and Social Scienceyang diselenggarakan oleh Fakultas Ekonomi UNY, tanggal (pp. 16-17).

Numrich, C. (1996). On becoming a language teacher: Insights from diary studies. Tesol Quarterly, 30(1), $131-153$. https://doi.org/10.2307/3587610

Seferoğlu, G. (2006). Teacher candidates' reflections on some components of a pre-service English teacher education programme in Turkey. Journal of education for Teaching, 32(4), 369-378. https://doi.org/10.1080/02607470600981953

Sikki, E. A. A., Rahman, A., Hamra, A., \& Noni, N. (2013). The competence of primary school English teachers in Indonesia. Journal of education and practice, 4(11), 139-145.

Sugiharti, S. (2016). Multidimensi Kompetensi Profesionalisme Guru. Prosiding Seminar Nasional Jurusan KSDPProdi S1 PGSD UNM, 121-128.

Wayne, A. J., \& Youngs, P. (2003). Teacher characteristics and student achievement gains: A review. Review of Educational research, 73(1), 89-122. https://doi.org/10.3102\%2F00346543073001089

Widiastuti, I. A. M. S., \& Md, I. A. (2016). EFL Teachers' Beliefs and Practices of Formative Assessment to Promote Active Learning. The ASIAN EFL Journal., 3.

Widiastuti, I. A. M. S., \& Saukah, A. (2017). Formative assessment in efl classroom practices. Bahasa dan Seni:

Jurnal Bahasa, Sastra, Seni, dan Pengajarannya, 45(1), 50-63.

http://journal2.um.ac.id/index.php/jbs/article/view/677/419 